\title{
Development Problems and Strategies of Business Administration in New Era
}

Jie Liu*

Meibang Longhe Financial Consulting Co., Ltd. E-mail: liujie@sina.com

Abstract: Under the background of the new era, to develop steadily for a long time, enterprises should pay attention to industrial and commercial management in internal management, formulate relatively perfect management system, improve the quality and efficiency of management by mobilizing the enthusiasm of employees, and promote the healthy and safe development of enterprises.

Keywords: New Era; Enterprise Development; Business Administration

\section{Introduction}

Under the background of the new era, if enterprises do not make innovations and changes in keeping with the times and still adopt the traditional business management mode, it will lead to the lag of their own development, and the efficiency of business management of enterprises cannot be improved, resulting in certain constraints on the development of enterprises. Therefore, in the current society, enterprise managers should actively change their business ideas and methods, introduce new management models, fully understand the development needs of business administration in the new era, and seriously consider the needs of enterprise development and the purpose of business administration based on the characteristics of the times, so as to promote the smooth development and efficiency of business administration in enterprises and provide a solid foundation for enterprise development.

\section{The significance of enterprises to carry out business administration}

\subsection{Improving the enterprise’s capital management system}

Under the background of the new era, due to the gradual increase of operating costs, enterprises need to continuously introduce new equipment, personnel and management methods in the process of development, which require a large amount of capital investment. Enterprise management is deeply influenced by traditional ideas, and there are certain ideological limitations in technological innovation and market expansion, and the reform is not thorough enough. Guided by the new business management model, enterprises introduce new management methods to ensure that they can realize the importance of market innovation, and then strengthen the allocation of enterprise resources, improve management level and quality, reduce unnecessary investment in the development of enterprises, as well as improve the overall operational efficiency of enterprises. Therefore, in the new era, if enterprises want to reduce investment and obtain better economic benefits, they need to pay attention to the implementation of industrial and commercial management, improve the enterprise fund management system and promote the more stable development of enterprises.

Copyright (C) 2020 Jie Liu

doi: 10.18282/bam.v2i2.1552

This is an open-access article distributed under the terms of the Creative Commons Attribution Non-Commercial License

(http://creativecommons.org/licenses/by-nc/4.0/), which permits unrestricted non-commercial use, distribution, and reproduction in any medium, provided the original work is properly cited. 


\subsection{Providing direction and path for enterprise development}

In the new era of increasingly fierce market competition, many enterprises can't cope with the impact of the changes of the times in their development. Some enterprises don't know how to operate, and even can't make decisions on production and investment, leading to the loss of sense of direction in their development and affects their normal operation. The development of industrial and commercial administration can help enterprises work out their development direction. Enterprises can find the law of market development through the role of industrial and commercial administration, recognize their own shortcomings, and take targeted strategies in actual management and operation to make up for the shortcomings, so as to provide scientific guidance for enterprise development and ensure the safe and stable operation of enterprises.

\subsection{Conducive to improving the quality of enterprise financial management}

Financial management is the core content of enterprise management and business administration. Financial management has a direct impact on business activities and is conducive to the long-term development of enterprises. Most enterprises' traditional financial management work is carried out in an extensive way, with some problems such as missing management work and chaotic management system. Enterprises should take industrial and commercial management as the leading factor, attach importance to financial management and improve financial management level, which is not only the premise of enterprise development, but also the embodiment of industrial and commercial management in enterprise financial management.

\section{Problems in business administration in enterprise development}

Whether it is based on market economy system or social management economy system, the role of business administration in business operation is very important. However, in the development of China's economic system integration, there are still many problems in business administration, such as the large number of business administration departments, complicated approval workflow and long time, which may lead to the loss of business opportunities, or loopholes and shortcomings in the financial management of many enterprises. Some enterprises even have no financial departments. In addition, the world economy is gradually developing towards integration, and the economic cooperation between China and domestic and foreign countries is constantly improving, making the competition in various industries become increasingly fierce. In this context, what enterprises need to do is to improve and implement the business management, make up for the shortcomings of the traditional business management model, ensure that the business management can be strengthened, and the work efficiency and level can be improved.

\subsection{Lack of risk control system}

By investigating the actual management situation in the process of enterprise development, it can be known that most enterprises attach importance to the proportion of market share, emphasize the enterprise development, but ignore the internal business management and risk prevention and control. If an enterprise wants to establish a sound industrial and commercial management system, it needs to consume manpower and financial resources. However, in actual operation, most enterprises blindly carry out cost control, and still use the traditional management mode. Compared with the new management mode, the traditional management concepts and methods have fallen behind and cannot meet the needs of today's social development. The development of society is constantly changing, while the corporate management mode of enterprises is stagnant, unable to play its due role and serve enterprises better. At the same time, although some enterprise leaders have noticed the deficiency of management mode and understood that business administration is of great significance to enterprise development, some of them only understand part of the contents and are unable to fully understand and master the essence of business administration system and risk control. In actual application, they just follow and implement others' management modes. In this way, the business administration system and risk control system of enterprises can not fully play a role, which is not conducive to the long-term stable development of enterprises. 


\subsection{Low quality and professional skills of business management personnel}

Specifically, the essential content of the competition between enterprises is the acquisition of talents, which is the core competitiveness of enterprises. The internal personnel or leaders and responsible persons play an important role in the development of enterprises, are the direct influencing factors of the development of enterprises, and have far-reaching significance for the future development of enterprises. Therefore, if an enterprise wants to improve its own level, it must strengthen personnel training, make its employees become excellent, improve their overall quality, and provide guarantee for the good development of the enterprise. For some enterprises at present, employees have uneven quality level, noncomprehensive understanding of relevant policies and regulations, insufficient professional skills and deeply-rooted traditional ideas. Therefore, the management level of enterprises in China needs to be improved, and the enterprises managers are not outstanding enough in professional skills and management level. This also reflects that in the process of development, enterprises ignore the improvement of personnel training and management, pay more attention to benefits in a short time, and do not carry out staff training activities. Employees are the foundation of enterprises, and the lack of progress of internal employees will also affect the development of enterprises. Enterprises will gradually weaken their core competitiveness with the change of time, affecting the long-term stable development of enterprises.

\section{Business administration strategies of enterprises}

\subsection{To improve the self-quality of enterprise staff}

Business managers are particularly important for the development of enterprises, and their work content is mainly responsible for the work management of enterprises and supervising every link. To ensure the normal and effective management of enterprises, it is necessary to improve the management level and comprehensive quality of enterprise managers, and to achieve several key contents. First, enterprises should adjust their personnel in time according to their own development, and find outstanding talents to inject fresh vitality into enterprises. At present, the market situation is ever-changing, and the relevant person in charge of the enterprise should assign different work contents according to the personal abilities of employees, so as to ensure that the enterprise personnel can play the greatest role, and at the same time, the enterprise can better cope with the changes in the market and take effective measures in the development process. Second, the company should carry out regular training activities, which can train employees and professional skills, and also train employees' management level, so that employees can keep learning and understand the updated market trends, establish business management concepts, put themselves in the interests of the company's development and provide better help for the company. Through regular training activities, the core competitiveness of enterprises can be enhanced and employees can play a greater role in practical work.

\subsection{To create a complete industrial and commercial management system}

It is necessary to establish a sound industrial and commercial management system to provide better services for enterprises in the new society. The emergence of new occupations has brought novelty to the market economy. On the whole, establishing a perfect industrial and commercial management system can better cope with the changes and development of the new era, which is of great significance to the competitiveness of enterprises, so it is necessary to constantly improve the industrial and commercial management system. With the continuous development of society, the types of social occupations have undergone earth-shaking changes, resulting in a variety of new occupations. Managers should learn to adapt to and accept the new market, change their focus into encouragement, help enterprises adapt to the new market, and provide a good living space. At the same time, it is necessary to increase the contact and communication between different units, so as to learn and make progress together, continuously improve the management ability of enterprises and the comprehensive quality of personnel, give play to their own identity value, and provide an excellent environment for market players

\subsection{To strengthen the informatization construction of business administration}

At present, all walks of life in the market are actively transforming, integrating Internet technology into the devel- 
opment process of enterprises. Business administration should also strengthen the informatization construction of related work, not only to strengthen the intelligence and informatization of external windows, but also to carry out informatization construction of internal information processing of enterprises. Through informatization construction, it can greatly improve the work efficiency of office workers, reduce the investment in labor, the speed of people's improve the inquiry and business processing, and improve people's satisfaction with business administration. In addition, strengthening information construction can also facilitate enterprises to assess and supervise internal employees. The industrial and commercial administration departments can realize real-time supervision of employees' work and early warning of enterprise anomalies through diversified technical means, which can effectively improve the scope of supervision and work efficiency. Therefore, under the background of the new era, industrial and commercial administration should pay attention to the degree of informatization construction, improve its modernization process, and enable enterprises to transform rapidly.

\subsection{To establish a sound social supervision system}

Among them, the staff in charge of business administration need strong support from all walks of life and employees in enterprises to supervise the law enforcement process of the staff. In addition, people from all walks of life need to pay close attention to the current situation of the market and the information of commodities. In this process, violations of laws and regulations are checked through various channels, so that the supervisory role of the people can be fully exerted. In addition, the relevant personnel and departments need to constantly improve the infrastructure, promote the improvement of supervision conditions, and then enhance the function of the social supervision system, so that it can better play its supervisory role.

\section{Conclusion}

To develop steadily in the new era, enterprises should pay attention to the importance of internal business administration, strengthen the implementation of business administration, form a good atmosphere within the enterprise, enhance and cultivate the sense of responsibility and work quality of employees, thus providing a good foundation for the transformation and development of enterprises.

\section{References}

1. Fu S. The development trend of business administration in the new era (in Chinese). New Silk Road: Early 2020; (4): 1.

2. Huang W. Strategies for improving the management effectiveness of industrial and commercial enterprises in the new era (in Chinese). Chinese and Foreign Entrepreneurs 2019; 660(34): 35.

3. Ning J. Discussion on the effective strategy of improving the management of industrial and commercial enterprises under the background of the new era (in Chinese). Think Tank Times 2019; (40): 279.

4. Li D. Business administration measures in the new era (in Chinese). Public Relations World, 2020; 471(4): 102103. 